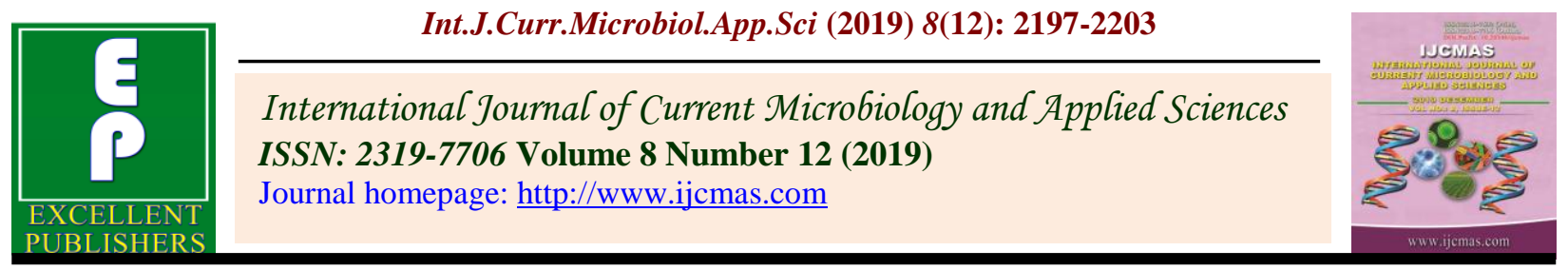

Original Research Article

https://doi.org/10.20546/ijcmas.2019.812.261

\title{
Seasonal Incidence of Aphid, Aphis craccivora (Koch) Infecting Yard Long Bean, Vigna unguiculata sub spp. Sesquipedalis
}

\author{
Ramesh*, M. Maradi, K. Rajashekharappa, B. K. Shivanna, \\ H. K. Veeranna and Nagarajappa Adivappar
}

Department of Agricultural Entomology, College of Agriculture, Shivamogga University of Agricultural and Horticultural Sciences, Shivamogga-577225, India

*Corresponding author

\section{A B S T R A C T}

\section{Keywords}

Yard long bean,

Aphids,

Temperature,

Rainfall, Long

Podded cowpea,

Snake bean

Article Info

Accepted:

17 November 2019

Available Online:

10 December 2019
The investigation was carried out to know the seasonal incidence of aphids and their level of infestation on yard long bean during Kharif 2018 and Rabi 2018-19 at AHRS, Bhavikere, UAHS, Shivamogga, Karnataka. The short duration yard long bean variety Arka Mangala was found infested with many number of sucking pests at various stages of crop growth. Among the different sucking pests recorded on yard long bean, aphids, Aphis craccivora Koch was the major pest causing yield loss under open field condition. The incidence of aphid was noticed throughout the cropping period. During Kharif the aphid population ranged from 2.82 to 72.37 aphids per leaf. Whereas during Rabi the aphid population ranged from 1.20 to 79.57 aphids per leaf. During Kharif the incidence of aphids was significant and positively correlated with the maximum temperature, maximum relative humidity and minimum relative humidity. Whereas, minimum temperature and rainfall showed a significant and negative correlation with aphid population. During Rabi, it was significant and positively correlated with the maximum and minimum temperature, rainfall and maximum relative humidity. Whereas, minimum relative humidity shows a non-significant negative correlation with the aphid population.

\section{Introduction}

Yard long bean, Vigna unguiculata sub spp. sesquipedalis is a delicious fresh vegetable belonging to the family Fabaceae. It is also known by other names like asparagus bean, sting bean, long podded cowpea, snake bean and body bean (Purseglove, 1977). It is a highly nutritive vegetable containing a good amount of digestible protein both in pods (23.5 - 26.3\%) and in leaves (Ano and Ubochi, 2008). It can be used as fodder, vegetable, green legume as well as green manure crop. The area of yard long beans in India is about 
18,560-20,160 ha (Saurabh et al., 2018). The yard long bean was originated probably in the Middle West Africa or Southern China. In India, Kerala contributes a major share, accounting for nearly 90 per cent in terms of both area and production followed by Karnataka and Tamil Nadu. During the cultivation, the farmer faces various problems in pest management (Rashid, 1993). The important constraints for lowering yield and poor quality of yard long bean is incidence of insect pests. The major insect pests which severely damage yard long bean during all growth stages are the bean aphid, $A$. craccivora, leaf hopper, Emposca terminalis Distanct, thrips, Megalurothrips usitatus and red spider mites, Tetranychus urticae. Among these, A. craccivora was the major one and it has been reported as a cosmopolitan species causing direct and indirect (as vectors) damage to the cultivated crops (Grubben, 1993). About 150 species of insect pests are known to attack beans in India, of which about 25 species are reported to be serious (Srivastava, 1987). The yield loss in yard long bean due to aphids is reported to be about 1230 per cent (Hossain and Awrangzeb, 1992). Reports on incidence of insect pests and their management techniques for the yard long beans in its major growing areas of India are limited. Review of literature revealed that in our state, no work has been conducted on the insect pests of the yard long bean. The present study was, therefore, undertaken to know the incidence of aphids and their level of infestation under different conditions on yard long bean.

\section{Materials and Methods}

Investigations on seasonal incidence of aphids on yard long bean was carried out by raising crop in two seasons during 2018-2019 at AHRS, Bhavikere, UAHS, Shivamogga, Karnataka. Arka Mangala variety of yard long bean was sown with a spacing of $120 \mathrm{~cm}$ x 30 $\mathrm{cm}$ in a gross plot size of $660 \mathrm{~m}^{2}$ area. The crop was raised as per package of practices except plant protection measures against sucking pests. The field experiment was laid out in randomized block design (RCBD) with nine treatments and three replications comprising of different newer molecules of insecticides along with untreated control.

Observations were recorded on 10 randomly selected and tagged plants at weekly interval from one week after sowing by adopting standard procedures. The adults and nymphs of aphids were counted from three leaves i.e., one each from top, middle and bottom canopy of ten randomly selected plants. Total number of aphids from each plant was estimated and the population was expressed in terms of mean number of aphids per leaf.

\section{Statistical analysis}

All the data recorded were subjected to statistical analysis as per the randomized block design procedure. The data was subjected to the ANOVA. The mean population of aphids correlated with the meteorological data ie., maximum, minimum temperature, maximum, minimum relative humidity and rainfall.

\section{Results and Discussion}

Seasonal activity of aphids, Aphis craccivora during Kharif 2018

During Kharif season, the incidence of aphid, Aphis craccivora was observed throughout the cropping period. It was first noticed during the $34^{\text {th }}$ standard week and continued upto the $48^{\text {th }}$ standard week. The population ranged from 2.82 to 72.37 aphids per leaf. The peak incidence was observed during $45^{\text {th }}$ standard week (Table 1). Whereas, the lowest population recorded during the $34^{\text {th }}$ standard week (2.82 aphids per leaf). These results were similar with the findings of Rekha and 
Mallapur (2007) reported that the aphid, $A$. craccivora peak incidence was noticed in large number from September to first week of October with a population range of 30.5 to 50.0 and 8.4 to 11.2 aphids per three leaves, respectively

\section{Impact of weather on aphid population}

The incidence of aphids was significant and positively correlated with the maximum temperature $(\mathrm{r}=0.533)$, maximum relative humidity $(\mathrm{r}=0.500)$ and minimum relative humidity $(\mathrm{r}=0.719)$. Whereas, minimum temperature $(\mathrm{r}=-0.293)$ and rainfall, $(\mathrm{r}=$ 0.575) showed a significant and negative correlation with the aphid population at five per cent level of significance. The equation obtained when the data was subjected to multiple linear regression analysis was $\mathrm{Y}=$ 90.320-0.691X1+3.805X2-

$2.074 \times 3+0.039 \times 4+0.428 \times 5+12.890$. Where $\mathrm{X} 1=$ total rain fall, $\mathrm{X} 2=$ maximum temperature, $\mathrm{X} 3=$ minimum temperature, $\mathrm{X} 4=$ maximum relative humidity, $\mathrm{X} 5=$ minimum relative humidity (Table 3 )

This is in line with the results of Prasad et al., (2008) who reported that during Kharif season, the population of $A$. craccivora was influenced negatively with minimum temperature and rainfall. Similar results were recorded by Kumar and Kumar (2015) who recorded highest aphid population of 32.12 per leaf in cowpea field during Kharif season. The population of aphid influenced positively by relative humidity. The negative correlation was found between aphid and maximum temperature. This difference might be due to the weather condition prevailing during study period and also due to change in data of planting during Kharif.
Seasonal activity of aphids, Aphis craccivora during Rabi 2018-19

During rabi season, the incidence of aphid, $A$. craccivora was noticed from the $52^{\text {nd }}$ standard week with 1.20 aphids per leaf and continued upto the $13^{\text {th }}$ standard week and recorded 64.70 aphids per leaf. However, its population ranged from 1.20 to 79.57 aphids per leaf. The peak incidence was observed during $12^{\text {th }}$ standard week with 79.57 aphids per leaf. Whereas, lowest population of 1.20 aphid per leaf was recorded during the $52^{\text {nd }}$ standard week (Table 2).

\section{Impact of weather on Aphid population}

The incidence of aphids was significant and positively correlated with the maximum temperature $(r=0.860)$, minimum temperature $(\mathrm{r}=0.765)$ and maximum relative humidity $(\mathrm{r}$ $=0.534)$. Whereas, minimum relative humidity ( $\mathrm{r}=-0.381$ ) shows a non-significant negative correlation with the aphid population at five per cent level of significance. The equation obtained when the data subjected to multiple linear regression analysis was $\mathrm{Y}=$ 152.67+6.139X1+5.267X2+1.194X3-0.029X4 +11.480 . The value of coefficient of determination $\mathrm{R}^{2}$ revealed that the seasonal incidence of bean aphid was influenced by weather parameters to the extent of 86.70 per cent (Table 3).

This result is in close conformity with the findings of Kataria and Kumar (2016) who studied the seasonal incidence of $A$. craccivora on bean crop. They reported that the maximum population of pest was seen in the month of January to March. The aphid population showed positive correlation with high temperature. 
Table.1 Seasonal incidence of sucking pests of yard long bean during Kharif 2018

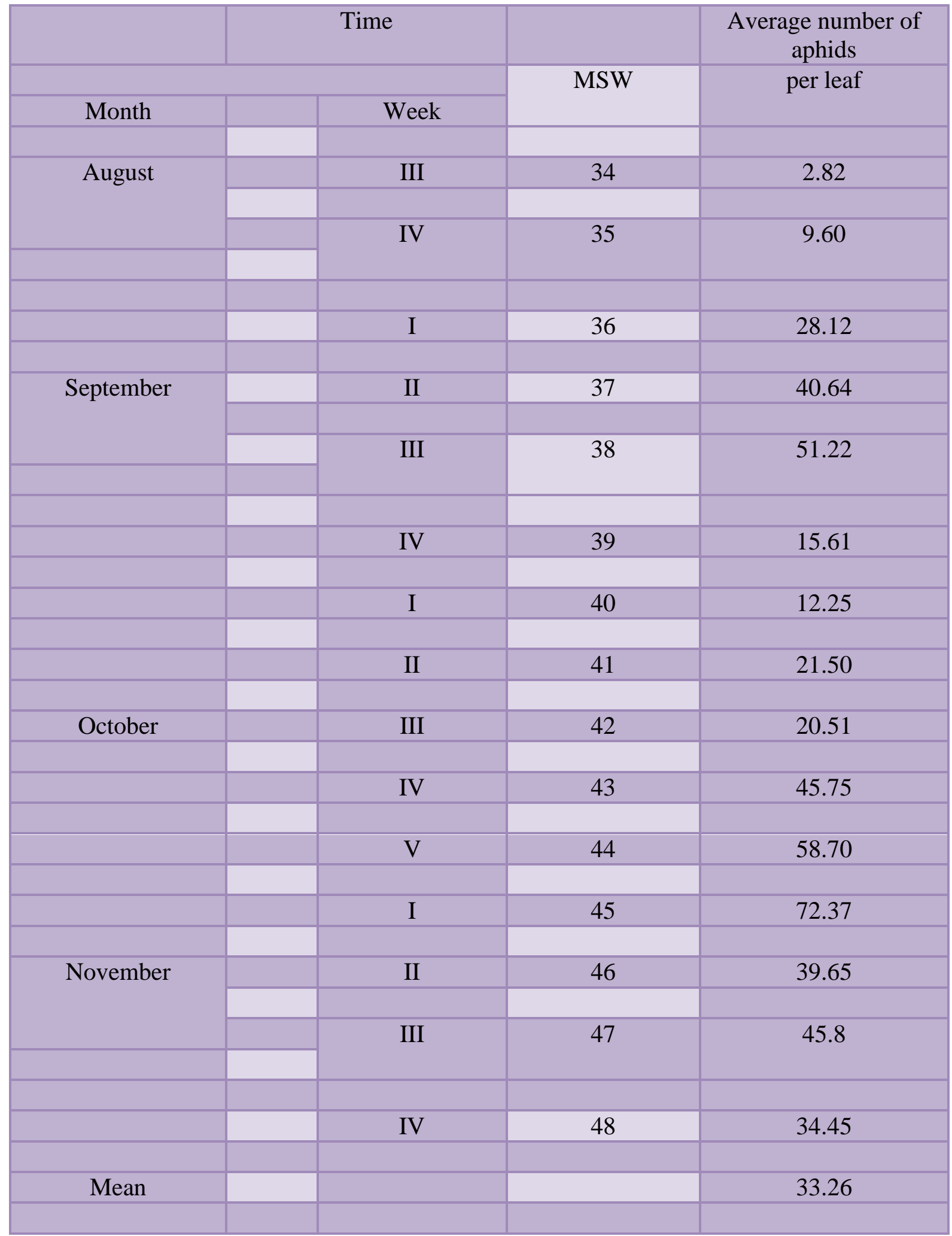

Note: MSW; Mean Standard Week 
Table.2 Seasonal incidence of sucking pests of yard long bean during Rabi 2018-19

\begin{tabular}{|c|c|c|c|c|}
\hline & & & & Average number of \\
\hline & & & & \\
\hline
\end{tabular}

Note: MSW; Mean Standard Week 
Table.3 Correlation and regression values for incidence of aphids and weather parameters during Kharif and Rabi 2018-19

\begin{tabular}{|c|c|c|c|c|c|c|c|}
\hline \multirow{3}{*}{ Season } & \multicolumn{5}{|c|}{ Correlation coefficient ( $r)$} & \multirow{3}{*}{$\begin{array}{c}\text { Co-efficient of } \\
\text { determination } \\
\text { (r2) }\end{array}$} & \multirow{3}{*}{ Regression Equation } \\
\hline & \multicolumn{5}{|c|}{ Meteorological parameters } & & \\
\hline & $\begin{array}{l}\text { Rainfall } \\
\left(\mathbf{X}_{\mathbf{1}}\right)(\mathbf{m m})\end{array}$ & $\begin{array}{l}\text { Max.Tem } \\
\left(\mathrm{X}_{2}\right)\left({ }^{0} \mathrm{C}\right)\end{array}$ & $\begin{array}{l}\text { Min.Tem } \\
\left(\mathrm{X}_{3}\right)\left({ }^{0} \mathrm{C}\right)\end{array}$ & $\begin{array}{c}\text { RH-I } \\
\left(\mathbf{X}_{4}\right)(\%)\end{array}$ & $\begin{array}{l}\text { RH-II } \\
\left(\mathbf{X}_{5}\right)(\%)\end{array}$ & & \\
\hline Kharif & $-0.575 *$ & $0.533^{*}$ & -0.293 & 0.500 & $0.719 * *$ & 0.706 & $\begin{array}{c}\mathrm{Y}=-90.320- \\
0.691 \mathrm{X}_{1}+3.805 \mathrm{X}_{2-} \\
2.074 \mathrm{X}_{3}+0.039 \mathrm{X}_{4}+0.428 \\
\mathrm{X}_{5}+12.89\end{array}$ \\
\hline Rabi & 0.264 & $0.860 * *$ & $0.765^{* *}$ & $0.534 *$ & -0.381 & 0.860 & $\begin{array}{c}\mathrm{Y}=- \\
152.67+6.139 \mathrm{X}_{1}+5.267 \mathrm{X}_{2} \\
+1.194 \mathrm{X}_{3-} \\
0.029 \mathrm{X}_{4}+11.480\end{array}$ \\
\hline
\end{tabular}

*Correlation is Significant at the 0.05 level; ** Correlation is Significant at the 0.01 level

In the present study also confirmative with the findings of Chundawat and Ameta (2011) and Siddarth et al., (2017) who reported that maximum temperature showed a significant positive correlation with population of aphids during Rabi 2014.

Further, both minimum temperature and average temperature showed a noteworthy positive effect on pest population during Rabi 2017.

The results of survey revealed that, during Kharif, the peak population of aphids was recorded during first week of September, leaf hoppers population recorded in third week of September, mites in first week of November and thrips incidence was highest during fourth week of September. Whereas, during Rabi, the aphid population was maximum during first week of January and thrips population recorded during second week of March.
While, leaf hopper and mite population was highest during second week of February.

\section{References}

Ano, A. O. and Ubochi, C. I,. 2008, Nutrient composition of climbing and prostrate vegetable cowpea accessions. A. J. Biotech., 7(20): 3795-3798.

Chundawat, A. S. and Ameta, O.P., 2011, Incidence of sucking insect pests of okra in relation to weather parameters. Ind. J. Appl. Entomol., 25 (1): 36-38.

Grubben, G. J. H., 1993, Vigna unguiculata (L) Walp. cv. group Sesquipedalis. In: Siemonsma, J.S. \& Kasem Piluek (Editors). Plant Resources of SouthEast Asia No 8. Vegetables. Pudoc Scientific Publishers, Wageningen, The Netherlands, pp. 274-278.

Hossain, A. and Awrangzeb, S. N. H., 1992, Vegetable production polices plan and 
future directions. Proceding on Vegetable production and marketing. AVRDC, BARI, BARC and USAID. pp. 21-30.

Kataria, R. and Kumar, D., 2016, Population dynamics of Tetranychus spp. (Koch) and its natural enemies on bean crop in relation to weather parameters in Vadodara, Gujarat, India. Legume Res., 40(3): 571-579.

Kumar, A. and Kumar, A., 2015, Effect of abiotic and biotic factors on incidence of pests and predator in cowpea [Vigna unguiculata (L.) Walp.]. Int. J. Leg. Res., 38(1): 121-125.

Prasad, T. V., Nandagopal, V. and Gedia, M., 2008, Effect of abiotic factors on the population dynamics of Aphis craccivora Koch in groundnut in Saurashtra region of Gujarat. Ind. J. Entomol., 70(4): 309-313.

Purseglove, J. W., 1977, Tropical crops (Dicotyledons) London. Longman Group Ltd., 273-276.
Rashid, M. M., 1993, Begun Paribarer Shabji. Shabji Biggan (in Bangla). Firsted. Bangla Academy, Dhaka, Bangladesh. 384-389 pp.

Rekha, S. and Mallapur, C. P., 2007, Abundance and reasonability of sucking pests of dolichos bean. Kar. J. Agric. Sci., 20(2): 397-398.

Saurabh, T., Devi, S. and Deepanshu., 2018, Evaluation trial in yard long bean (Vigna unguiculata ssp. Sesquipedalis (1.) Verdic.) in Allahabad agro-climatic condition. Global journal of bio science and bio technology, 7 (3): 447450 .

Siddartha, D., Kotikal, Y. K., Venkateshalu and Sanjiv, D., 2017, Seasonal incidence of sucking pests on okra. Global journal of bio science and bio technology, 6(2): 245-250.

Shrivastava, K. K., 1987, Evaluation of soybean varieties against stem fly, (Melanagromyza sojae) attack. Ind. J. pl. protec., 15: 168-169.

\section{How to cite this article:}

Ramesh, M. Maradi, K. Rajashekharappa, B. K. Shivanna, H. K. Veeranna and Nagarajappa Adivappar. 2019. Seasonal Incidence of Aphid, Aphis craccivora (Koch) Infecting Yard Long Bean, Vigna unguiculata sub spp. Sesquipedalis. Int.J.Curr.Microbiol.App.Sci. 8(12): 21972203. doi: https://doi.org/10.20546/ijcmas.2019.812.261 